\title{
HOFFMAN'S SYNDROME
}

\section{Pseudohypertrophic myopathy as initial manifestation of hypothyroidism}

\section{Case report}

\author{
Luiz Felipe Rocha Vasconcellos ${ }^{1}$, Maria Claudia Peixoto', Tatiana Nunes de Oliveira', \\ Glória Penque ${ }^{2}$, Ana Claudia Celestino Leite ${ }^{1}$
}

\begin{abstract}
The frequency of myopathy in hypothyroidism ranges from 30 to $80 \%$. The major symptoms related are weakness, muscular cramps and myalgia. The pseudohyperthrophic form is called Hoffman's syndrome. The electrophysiological study reveals myopathy, neuropathy or mixed pattern. Laboratorial investigation generally shows increased levels of muscle enzymes and low serum thyroid hormones, with thyrotrophic-stimulating hormone (TSH) elevated. The treatment consists in hormone replacement and the prognosis is good in most of the cases. We report an adult male who developed muscular cramps, myalgia, weakness, pseudohyperthrophy, associated with facial edema and alteration of his voice. The muscle enzymes were increased and T4 was undetectable with a raised level of TSH. The myopathy was the initial manifestation of hypothyroidism in this case.
\end{abstract}

KEY WORDS: myopathy, hypothyroidism, pseudohypertrophy.

\section{Síndrome de Hoffman: miopatia pseudohipertrófica como manifestação inicial de hipotireoidismo. Relato de caso}

\begin{abstract}
Resumo - A frequência de miopatia no hipotireoidismo varia de $30 \%$ a $80 \%$. Os sintomas relacionados ao acometimento muscular são fraqueza, cãimbras e mialgias. A forma pseudo-hipertrófica é denominada síndrome de Hoffman. $\mathrm{O}$ estudo eletrofisiológico pode revelar padrão miopático, neuropático ou misto. A investigação laboratorial em geral mostra aumento das enzimas musculares e redução dos níveis de hormônio tireoidiano com TSH elevado. O tratamento consiste na reposição oral de hormônio e o prognóstico é bom na maioria dos casos. Relatamos o caso de um adulto que apresentou cãimbras, mialgia, fraqueza com pseudohipertrofia muscular associados a edema facial e alteração da voz. As enzimas musculares estavam elevadas e o nível de T4 foi indetectável com aumento de TSH. A miopatia foi manifestação inicial de hipotireoidismo neste caso.
\end{abstract}

PALAVRAS-CHAVE: miopatia, hipotireoidismo, pseudo-hipertrofia.

The thyroid hormone is necessary to cell metabolism of all organic systems. Its deficiency is manifested by a systemic disease with insidious onset. The manifestations on the central nervous system (CNS), are characterized by psychiatric symptoms, cerebellar ataxia, cranial neuropathy and seizures'. An impairment of peripheral nervous system and muscles leads to different types of neuropathy and myopathy being responsible for $5 \%$ of acquired myopathies ${ }^{2}$. The myopathy associated with hypothyroidism could be divided in four subtypes: KocherDebré-Semelaigne syndrome, Hoffman's syndrome, atrophic form and myasthenic syndrome ${ }^{3}$. In the Kocher-Debré-Semelaigne syndrome described in infants with cretinism, as in the Hoffman syndrome, patients presented with hypertrophy, muscular we-

Institute of Neurology Deolindo Couto (INDC), Federal University of Rio de Janeiro (UFRJ) and University Hospital Clementino Fraga Filho (HUCFF), Rio de Janeiro RJ, Brazil: ${ }^{1} \mathrm{MD}$; $^{2}$ Department of Clinical Neurophysiology, INDC/UFRJ.

Received 13 November 2002, received in final from 7 April 2003. Accepted 9 May 2003.

Dr. Luiz Felipe Rocha Vasconcellos - Rua Barão da Torre 209/102 - 22411001 Rio de Janeiro RJ - Brazil. FAX: 552122843698. E-mail: luizneurol@hotmail.com 
akness, slowness of mental and locomotor activities. In Hoffman syndrome it is described also muscular cramps, stiffness post-exercise and pseudomyotonic phenomenon. Other less frequent presentations are atrophic myopathy and myasthenic syndrome with unsatisfactory response to edrophonium. In most of the cases, the level of muscular enzymes is elevated, with no relation to the severity of the myopathic symptoms ${ }^{4}$. In primary hypothyroidism, the hormonal dosage shows low circulating of thyroid hormones (T3 and T4) with elevated TSH. Once the hormonal reposition is started, the myopathy could be reversible with good prognosis. Although it is a rare condition, the myopathy may be the first presentation of hypothyroidism².

We present a case in which myopathy was the first symptom of autoimmune thyroiditis.

\section{CASE}

A, 42 years-old man admitted for diagnostic investigation of progressive muscular weakness with muscular cramps and myalgia started one year before. He had mentioned a gastric surgery for resection of an abdominal tumor (histological diagnostic of non-Hodgkin lymphoma) followed by treatment with chemotherapy nine years ago. Since then, he remained asymptomatic with normal clinical and laboratorial exams. We observed in clinical examination: infiltrated facies, macroglossia and the voice was hoarse cry, hypophonesis of heart sounds and sinusal bradycardia (56 bpm). On neurological examination was observed pseudohypertrophy (Fig 1) with proximal paresis of inferior limbs (Grade 4/5 Muscle Research Council [MRC]), generalized hyporeflexia, and superficial hypoesthesia on the distal superior limbs. On the exam of the cranial nerves, bilateral impairment of the cochlear portion of VIII nerve.

Laboratorial investigation reveals (Table 1): (1) increased serum levels of muscular enzymes; (2) mild elevation of serum level of creatinine; (3) leukopenia; (4) dislipidemia degree IV, (5) dosage of thyroid hormones compatible with primary hypothyroidism with raised levels of anti-thyroglobulin $(1977 \mathrm{u} / \mathrm{ml}$ - Normal: $40 \mathrm{u} / \mathrm{ml}$ ) and antiperoxidase(>1000 u/ml- Normal: $35 \mathrm{u} / \mathrm{ml}$ ), (6) electrocardiogram (ECG) showed sinus bradycardia with low voltage in the precordial leads, (7) electrophysiological study showed normal Desmet and repetitive stimulation test. The motor and sensitive neuroconduction did not revealed abnormalities. The first electromyography (February/2001) revealed a diminished recruiting of motor unit (neurogenic pattern). The second exam (April/2001) showed a mixed pattern (myogenic and neurogenic).

After ten days of thyroid hormone therapy, the patient referred improvement of the muscular cramps. Three months latter, he was asymptomatic. There was progressive lowering of the levels of muscular enzymes (Table 1).

\section{DISCUSSION}

The neurological manifestations of hypothyroidism usually occur after clinic impairment of other systems, so it is unusual to see it as the initial symptoms. Primary hypothyroidism accounts for $95 \%$ of

Table 1. Laboratorial exams.

\begin{tabular}{lccccccc}
\hline Period & T4 & TSH & TG & Cholesterol & CPK & LDH & AST \\
\hline Before treatment & $<0.2$ & 120 & 342 & 309 & 3.179 & 368 & 68 \\
$\begin{array}{l}\text { After treatment } \phi \\
\begin{array}{l}1 \text { month after) } \\
\text { VNO }\end{array}\end{array}$ & VNO & VNO & VNO & 1882 & 329 & 41 \\
$\begin{array}{l}\text { After treatment } \Upsilon \\
(3 \text { months after) }\end{array}$ & 0.7 & 24.58 & 175 & 145 & 144 & 184 & 28 \\
\hline
\end{tabular}

$\phi$ in use of $75 \mu \mathrm{cg}$ of thyroxine; $\Upsilon$ in use of $125 \mu \mathrm{cg}$ of thyroxine; T4 free thyroxine (N $0.71-1.85 \mathrm{ng} / 100 \mathrm{~mL}) ; \mathrm{TSH}$ thyrotrophic-stimulating hormone (N $0.47-5.01 \mathrm{mUl} / \mathrm{mL}) ; \mathrm{TG}$, triglyceride (N 10-170 mg/dL) Cholesterol (N 150 - $250 \mathrm{mg} /$ $\mathrm{dL}$ ); CPK, creatinophosphokinase (N 26 - $174 \mathrm{U} / \mathrm{L}$ ); LDH, lactic dehydrogenase (N $150360 \mathrm{UI} / \mathrm{L}$ ); AST, aspartate aminotransferase (N 12-46 U/L); VNO, value not obtained.

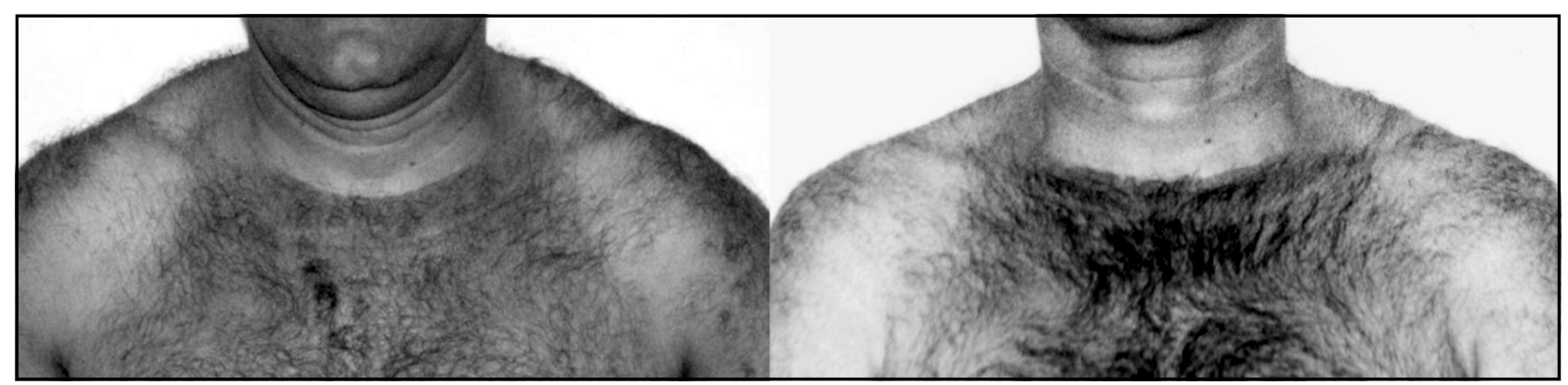

Fig 1. Before and after treatment showing the resolution of pseudohypertrophy. 
the cases of thyroid insufficiency. The main etiology is Hashimoto's thyroiditis, an autoimmune chronic thyroiditis characterized by high levels of antiperoxidase antibodies (anti-TPO) and anti-thyroglobulin, as documented in our case. Anti-thyroglobulin is present in $80-90 \%$ of the cases and anti-TPO may be present in $90-100 \%$ of the cases ${ }^{5}$. Signals and symptoms related to hypothyroidism myopathy usually include cramps, muscular weakness, myalgia, myxedema and hyporeflexia ${ }^{6}$. The myalgia may be so expressive that it resembles polymyositis in some cases $^{7}$. Rarely, exercise-induced myalgia secondary to recurrent rabdomyolisis could be an isolated manifestation ${ }^{8}$. Myokymia may be another peripheral manifestation and it seems to be related to sodium loss 9 . There are different clinical presentations of the myopathy: weakness with muscular pseudohypertrophy, muscular atrophy or myasthenic syndrome ${ }^{3}$.

The adult pseudohypertrophic form is named Hoffman syndrome ${ }^{10}$. It is a rare syndrome described by Hoffman in 1897. Our patient fits in this form. Clinically he presented with proximal weakness, muscular cramps, rigidity, myalgia and increase in muscular mass.

The laboratorial investigation usually shows increased levels of muscular enzymes. The creatinophosphokinase (CPK) is the best biochemical marker of myopaties. The other enzymes (aldolase, AST and ALT, LDH) have a complementary role in the absence of hepatopathy ${ }^{11}$. In a study performed by Gianpietro et al. to determined the most sensitive enzyme to investigated myopathy, the CPK was elevated in $60 \%$ cases, in the superior limit in $30 \%$ and normal in $10 \%$, showing that this enzyme is the best biochemical marker for the investigation of myopathies, because it is a low cost method, sensitive and easy to perform ${ }^{12}$. The level of CPK does not relate to the clinical picture in the case of hypothyroidism, the patient may be symptomatic and have a normal CPK level, or the opposite ${ }^{12,13}$. The alteration of the level of CPK may vary from low elevations to extremely raised levels ${ }^{14}$. The fall on the enzyme levels with the treatment occurs slowly, varying from weeks, months or even years ${ }^{7,12.15}$. In the presented case, muscular enzymes returned to normal values in three months.

The electrophysiological study may be compatible with neurogenic, myogenic, a mix of those patterns, or even normal. The findings compatible with myogenic pattern are diminished duration and amplitude of motor unit potential, increase in polyphasics, with voluntary contraction there is early recruiting of the short action motor units, spontaneous fibril- lations, positive waves and complex repetitive discharges $^{11,15}$. Cruz et al. showed, in a study with 16 patients with primary hypothyroidism, electrophysiological abnormalities in $87.5 \%$ of the patients, being $46.6 \%$ with myopathic pattern, $43.7 \%$ with neuropathic pattern (carpal tunnel syndrome), and $25 \%$ with a mixed pattern ${ }^{16}$. The referred patient presented mixed pattern with carpal tunnel syndrome. In the case, despite the expressive clinical improvement with normalization of muscular enzymes, some electroneurophysiological alterations persisted as early recruiting, polyphasics, and bilateral carpal tunnel syndrome.

Pseudohypertrophy etiology in Hoffman's syndrome remains obscure and a matter of discussion. It has been postulated that the mechanisms involved could include an increase in connective tissue, increase in the size of muscular fibers and increase of the number of muscular fibers ${ }^{6}$. Ono et $a^{6} .^{6}$, in a study made with cases of hypothyroidism causing myopathy, showed that the diameter of the type I and II fibers could be normal and there was not an increase in the connective tissue, so the hypertrophy of muscular fibers and increase in connective tissue may be absent in Hoffman's syndrome. The severity of the myopathic picture seems to be related to some findings of muscular biopsy. In severe cases there is atrophy of type II muscular fibers, associated to central core of the nucleus, mainly of the type II muscular fiber ${ }^{3}$. On optic microscopy the alterations are atrophy, necrosis, muscular fibers hypertrophy, increase in the number of nucleus, ring-shaped fibers, glycogen deposits and increase of connective tissue ${ }^{9}$. Ultra-structural analysis showed edema and mitochondrial inclusions, myofibrillar fragmentation, glycogen deposits, lipid granule, sarcoplasmatic reticulum dilatation, autophagic vacuole, changes in the central core and T tubule ${ }^{9}$.

There is an association between thyroid dysfunction and lymphoma treatment, which usually occurs after blanket radiotherapy ${ }^{17,18}$. Chemotherapy seems to reduce the incidence of hypothyroidism in patients treated with radiotherapy, because of its immunosupressor effect ${ }^{18}$. Radiotherapy and chemotherapy associated seems to elevate the incidence of thyroid nodules ${ }^{17,18}$. Probably radiotherapy is associated to hypothyroidism because it compromises thyroid tissue, leading to cellular destruction, and consequently a reduction of thyroid follicles, leading to releasing of auto antibodies against thyroid cells ${ }^{18}$. In the present case, as the patient was treated only with chemotherapy, there was not a relation between the lymphoma treat- 
ment and the thyroid dysfunction, being a fortuitous association with autoimmune thyroiditis.

The treatment consists on given synthetic thyroid hormone, in the form of thyroxin, and the dosage varies between 100 to $200 \mu \mathrm{g} /$ day. Patients should be evaluated for cardiovascular risks previously to treatment because the risk of acute coronary insufficiency, especially in elderly. Some patients with severe myopathic manifestations may present a worsening in the beginning of the treatment, probably caused by the raise of metabolic demand induced by thyroxin ${ }^{3}$. In these cases, it is recommended the concomitant use of corticotherapy during some time of the treatment, as membrane-stabilizing effect ${ }^{3}$.

In conclusion, the etiology of myopathy in the related case was associated with autoimmune thyroiditis in a patient with previous history of nonHodgkin lymphoma. There was resolution of the symptoms with three months of treatment in use of thyroxin (150 $\mu \mathrm{g} /$ day). It is an infrequent cause of myopathy, with good prognosis.

\section{REFERENCES}

1. Bradley WG, Daroff R, Fenichel G, Marsden CD. Neurology in clinical practice. 3.Ed. Boston: Butterworth Heinemann, 2000:1009-1034.

2. Fessel WJ. Myopathy of hypothyroidism. Ann Rheum Dis 1968;27:590-596.

3. McKeran RO, Slavin G, Ward P, Paul E, Mair WGP. Hypothyroid myopathy: a clinical and pathological study. J Pathol 1980;132:35-54
4. Duyff RF, Bosch JV, Laman DM, Loon BJP, Linssen WHJP. Neuromuscular findings in thyroid dysfunction: a prospective clinical and eletrodiagnostic study. J Neurol Neurosurg Psychiatry 2000;68:750-755.

5. Larsen PR, Davies TF, Hay ID. the thyroid gland. In Williams textbook of endocrinology, 9.Ed. Philadelphia W.B. Saunders Company, 1998:401-406.

6. Ono S, Inouye K, Mannen T. Myopathology of hypothyroid myopathy: some new observations. J Neurol Sci 1987;77:237-248.

7. Toscano A, Bartolone S, Rodolico C, et al. Onset of hypothyroidism with polymyositis-like clinical features in elderly patients. Arch Gerontol Geriatr 1996;22/23,Suppl 5:537-576.

8. Lochmuller H, Reimers CD, Fischer P, Heub D, Höcker JM, Pongratz DE. Exercise-induced myalgia in hypothyroidism. Clin Investig 1993;71:999-1001.

9. Anagnos A, Ruff RL, Kaminski HJ. Endocrine neuromyopathies. Neurol Clin 1997;15:673-696.

10. Golding DN. Hypothyroidism presenting with musculoskeletal symptoms. Ann Rheum Dis 1970;29:10-14.

11. Laing NG, Mastaglia FL. Investigation of muscle disease. J Neurol Neurosurg Psychiatry 1996;60:256-274.

12. Giampietro O, Clerico A, Buzzigoli G, Chicca MG, Boni C, Carpi A. Detection of hypothyroid myopathy by measurement of various serum muscle markers: myoglobin, creatine kinase, lactate dehydrogenase and their isoenzymes. Hormone Res 1984;19:232-242.

13. Brewster LM, Visser M. Persistent hyperckemia: fourteen patients studied in retrospect. Acta Neurol Scand 1988;77:60-63.

14. Finsterer J, Stöllberger C, Grossegger V, Kroiss A. Hypothyroid myopathy with unusually high serum creatine kinase values. Hormone Res 1999;52:205-208.

15. Torres CF, Moxley RT. Hypothyroid neuropathy and myopathy: clinical and electrodiagnostic longitudinal findings. J Neurol 1990;237:271-274.

16. Cruz MW, Tendrich M, Vaisman M, Novis SAP. Electroneuromyography and neuromuscular findings in 16 primary hypothyroidism patients. Arq Neuropsiquiatr 1996;54:12-18.

17. Weber JC, Dufour P, Maloisel F, et al. Myopathie hypothyroïdienne hypertrophique après irradiation en mantelet pour maladie de Hodgkin: une observation. Rev Med Interne 1991;12:205-208.

18. Tamura K, Shimaoka K, Friedman M. Thyroid abnormalities associated with treatment of malignant lymphoma. Cancer 1981;47:2704-2711. 